\title{
The Antioxidant Properties of Pectin Fractions Isolated from Vegetables Using a Simulated Gastric Fluid
}

\author{
Vasily V. Smirnov, ${ }^{1}$ Victoria V. Golovchenko, ${ }^{1}$ Fedor V. Vityazev, ${ }^{1}$ Olga A. Patova, \\ Nikolay Yu. Selivanov, ${ }^{2}$ Olga G. Selivanova, ${ }^{2}$ and Sergey V. Popov ${ }^{1}$ \\ ${ }^{1}$ Institute of Physiology, Komi Science Centre, The Urals Branch of the Russian Academy of Sciences, \\ 50 Pervomaiskaya St., Syktyvkar 167982, Russia \\ ${ }^{2}$ Institute of Biochemistry and Physiology of Plants and Microorganisms, Russian Academy of Sciences, \\ 13 Prospekt Entuziastov, Saratov 410049, Russia
}

Correspondence should be addressed to Vasily V. Smirnov; smirnov@physiol.komisc.ru

Received 28 February 2017; Revised 3 May 2017; Accepted 9 May 2017; Published 11 June 2017

Academic Editor: Luis F. Guido

Copyright (C) 2017 Vasily V. Smirnov et al. This is an open access article distributed under the Creative Commons Attribution License, which permits unrestricted use, distribution, and reproduction in any medium, provided the original work is properly cited.

The antioxidant properties of vegetable pectin fractions against intraluminal reactive oxygen species were elucidated in vitro in conjunction with their structural features. The pectin fractions were isolated using a simulated gastric fluid ( $\mathrm{pH} 1.5, \mathrm{pepsin} 0.5 \mathrm{~g} / \mathrm{L}$, $37^{\circ} \mathrm{C}, 4 \mathrm{~h}$ ) from fresh white cabbage, carrot, onion, and sweet pepper. The fraction from onion was found to inhibit the production of superoxide radicals by inhibiting the xanthine oxidase. The high molecular weight of onion pectin and a large number of galactose residues in its side chains appeared to participate in interaction with xanthine oxidase. All the isolated pectic polysaccharides were found to be associated with protein $(2-9 \%)$ and phenolics $(0.5-0.7 \%)$ as contaminants; these contaminants were shown to be responsible for the antioxidant effect of vegetable pectin fractions against the hydroxyl and 1,1-diphenyl-2-picrylhydrazyl radicals.

\section{Introduction}

Epidemiological studies have shown that a diet rich in vegetables significantly reduces the incidence of chronic diseases including gastrointestinal disorders [1, 2]. The beneficial health effects of vegetables are believed to be attributable to the antioxidants contained in them, which could scavenge reactive oxygen species (ROS). Secondary metabolites (phytochemicals) of low molecular weight, particularly phenolics, have been shown to exhibit systemic antioxidant effects [3]. However, secondary metabolites of low molecular weight appear to possess an insufficient antioxidant activity against extracellular ROS formed in the intestinal lumen and mucosa. Indeed, antioxidant activity of phytochemicals against intraluminal ROS was to be limited by structural modifications of phytochemicals and/or their rapid elimination from the lumen due to absorption. Moreover, phytochemicals have been shown to exert prooxidant effects under certain conditions [4]. Antioxidants from vegetables which are resistant to digestion and absorption are supposed to provide scavenging of extracellular ROS generated from prooxidants found in food such as iron, copper, heme, and lipid peroxides [5]. In addition, intraluminal vegetable antioxidants may inhibit ROS formation during local infection, ischemia/reperfusion, gastric acid production, and nonsteroidal anti-inflammatory drugs [6].

Pectin is well known to be an important component of the primary cell wall and intracellular substance of higher plants [7]. As a ubiquitous component of fruits and vegetables, pectin is a natural component of the human diet and is considered as a constituent of dietary fibre due to be resistant in the human stomach and small intestine [8, 9]. Pectins have previously been shown to possess diverse biological activities, which may have a role in the beneficial effects of fruit and vegetable diets. Specifically, pectins have been found to possess ROS scavenging activity which is known to depend on the structural features of pectin [10-12]. 
Pectic polysaccharides are composed of a backbone of $(1 \rightarrow 4)$-linked $\alpha$-D-galacturonic acid (GalUA) residues. The homogalacturonic (HG) regions are interrupted by rhamnogalacturonic $(\mathrm{RG})$ regions containing $(1 \rightarrow 2)$-linked $\alpha$-Lrhamnose (Rha) residues. Rhamnosyl units can be substituted by side chains containing arabinose (Ara) and galactose (Gal) [13].

Pectin composition in the most of vegetables has been earlier investigated [14]. However, antioxidant activity of vegetable pectins as well as its dependence on structural features remains little studied. Raw polysaccharide extracts have been shown to possess the higher antioxidant activity than purified extracts [15]. The antioxidant activity of pectins was suggested to be increased by nonpectin contaminants (phenols and proteins) that were coextracted with them $[16,17]$. Therefore, investigating the capacity of the digestive process to release antioxidant crude pectic polysaccharides from plant cell wall matrix (i.e., bioaccessibility) is of great interest and is a first step in the determination of the beneficial potential of vegetable-based food. Here, we characterize pectin fractions isolated from fresh vegetables using a simulated gastric fluid and elucidate the antioxidant properties of these compounds in vitro. Cabbage, carrot, onion, and sweet pepper were chosen as the highly consumed fresh vegetables according to FAO data [18]. Moreover, the antioxidant activity of these vegetables has not been tested earlier.

\section{Materials and Methods}

2.1. Isolation of Pectin Fractions. Fresh white cabbage (Brassica oleracea convar. capitata var. alba L.), carrot (Daucus carota subsp. sativus (Hoffm.) Arcang.), onion (Allium cepa var. cepa (yellow onion)), and sweet pepper (Capsicum annum var. annum (red bell pepper)) (1 kg each) were homogenized using a blender and treated with simulated gastric fluid (10 L, pH 1.5). The simulated gastric fluid was composed of $\mathrm{HCl}(37 \mathrm{mM}), \mathrm{NaCl}(37 \mathrm{mM}), \mathrm{KH}_{2} \mathrm{PO}_{4}$ (4.6 mM), $\mathrm{CaCl}_{2}$ (1.1 mM), $\mathrm{KCl}(5.2 \mathrm{mM})$, and pepsin $(0.50 \mathrm{~g} / \mathrm{L}, \mathrm{EC} 3.4 .23 .1)$ [19]. Extracts obtained were filtered and centrifuged in a flow centrifuge at $10000 \mathrm{rpm}$ (Avanti J-25I, Beckman Coulter) for $1 \mathrm{~h}$ at $4^{\circ} \mathrm{C}$. The supernatants were collected and passed through an ultrafiltration cell containing a membrane with a molecular weight cutoff of $300 \mathrm{kDa}$. A high molecular weight cutoff membrane $(300 \mathrm{kDa})$ was used to prevent contamination with lower molecular weight antioxidant proteins such as superoxide dismutase, catalase, glutathione peroxidase, and ascorbate peroxidase (molecular weight of 30-135, 50, 80, and $100 \mathrm{kDa}$, resp.). The ultrafiltration process lasted 5-8 hours, until a negative reaction was obtained for the presence of sugars using Smith's procedure. The residual material was lyophilized to yield pectin fractions BO-P, DC-P, AC-P, and CA-P. The obtained fractions appear not to contain other phytochemicals of low molecular weight; UV-Vis spectra $(200-800 \mathrm{~nm}$, step $10 \mathrm{~nm})$ indicate the absence of any such contaminants.

2.2. General Analytical Methods. The content of uronic acids was determined by reacting 3,5-dimethylphenol with concentrated $\mathrm{H}_{2} \mathrm{SO}_{4}$ [20] and measuring absorbance at 400 and $450 \mathrm{~nm}$ with $\mathrm{D}$-galacturonic acid as the standard. A quantitative determination of protein concentration was performed using the Bradford method with bovine serum albumin as the standard. The number of methoxy groups was determined at $412 \mathrm{~nm}$ using methanol as the standard as has been previously described [21]. The degree of methyl esterification (DM), defined as the percentage of GalUA units esterified by methanol, was calculated using the following equation: $\mathrm{DM}=$ (moles methanol/moles uronic acid) $\times$ 100 [22]. Spectra were measured on an Ultrospec 3000 spectrophotometer. The quantitative determination of phenolics was performed with the Folin-Ciocalteu reagent using ferulic acid (Sigma-Aldrich) as the standard [16]. Enzymatic digestion of pectic polysaccharides was carried out by the treatment of samples with pectinase (690 unit/mg, Sigma, Germany) and was controlled according to Nelson [23] to estimate the reducing sugar quantities.

The molecular weight of the samples was determined by high-performance liquid chromatography (HPLC). The samples (3 mg each) were dissolved in $1 \mathrm{~mL}$ of $0.15 \mathrm{M} \mathrm{NaCl}$ and filtered. The chromatographic system Shimadzu (Japan) used for the analysis consisted of a LC-20AD pump, a DGU-20A3 degasser, a CTO-10AS thermostat, a RID-10A refractometer as the detector, and a Shodex OH-pak SB$804 \mathrm{HQ}$ column $(7.6 \mathrm{~mm} \times 30 \mathrm{~cm})$ with a GS-2G 7B Shodex precolumn $(7.6 \mathrm{~mm} \times 5 \mathrm{~cm})$. Pullulans from Fluka, Germany $(1.3,6,12,22,50,110,200,400$, and $800 \mathrm{kDa})$ were used as standards. Elution was carried out with $0.15 \mathrm{M} \mathrm{NaCl}$ $\left(40^{\circ} \mathrm{C}, 0.4 \mathrm{~mL} / \mathrm{min}\right)$. The average molecular weight $(\mathrm{Mw})$, average molecular weight number $(\mathrm{Mn})$, and polydispersity factor $(\mathrm{Mw} / \mathrm{Mn})$ were calculated using the LCsolution GPC program (LCsolution, version 1.24 SP1, Shimadzu, Japan).

The solutions were concentrated in a rotary evaporator under reduced pressure at $40-45^{\circ} \mathrm{C}$, centrifuged at 5000-6000 rpm for 10-20 min, and lyophilized. Samples were lyophilized in frozen state using the VirTis lyophilizer (USA) at a constant vacuum of $<10$ mTorr and a temperature of $-65^{\circ} \mathrm{C}$. Samples were periodically removed and weighed to ensure constant weight after $6 \mathrm{~h}$ and dried for a longer period if the weight of the sample had changed more than $5 \%$ during the last $2 \mathrm{~h}$ of lyophilization.

The monosaccharide composition was determined after the hydrolysis of the polysaccharides, where $2 \mathrm{M}$ aqueous trifluoroacetic acid (TFA) $(1 \mathrm{ml})$ containing myoinositol $(0.5 \mathrm{mg} / \mathrm{ml})$ was added to a weighed portion $(2-3 \mathrm{mg})$ of the polysaccharide sample. The mixture was incubated for $5 \mathrm{~h}$ at $100^{\circ} \mathrm{C}$. The excess acid was removed by the repeated evaporation of the hydrolysate to dryness with methanol. The mixture of monosaccharides was transformed into their alditol acetates and identified by gas-liquid chromatography (GLC) on a Varian 450-GC chromatograph (Netherlands) equipped with a flame-ionisation detector. GLC was run on a VF-5 ms capillary column $(0.25 \mathrm{~mm}, 30 \mathrm{~m})$ using the temperature regime of $175^{\circ} \mathrm{C}(1 \mathrm{~min})$ to $250^{\circ} \mathrm{C}(2 \mathrm{~min})$, at a rate of $3^{\circ} \mathrm{C} / \mathrm{min}$.

For amino acid analysis, samples were hydrolyzed in $6 \mathrm{M} \mathrm{HCl}$ for $24 \mathrm{~h}$ at $110^{\circ} \mathrm{C}$ in three independent repetitions. The amino acid identification was performed by precolumn 
derivatization with 6-aminoquinolyl-N-hydroxysuccinimidyl carbamate (AccQ) [24]. The separation of amino acids was performed on a Knauer Smartline 5000 HPLC system by reverse phase chromatography on a Diasphere $2 / 150 \mathrm{~mm}$ column: C18/2, $110 \mathrm{~A}$ pore size, $5 \mu \mathrm{m}$ mesh. The equimolar amino acid mixture AA-S-18 Amino Acid Standard Solution (Fluka, Germany) was used as a standard.

The flow behaviors of $1 \% \mathrm{w} / \mathrm{v}$ aqueous solutions of pectin fractions were measured using a Brookfield programmable viscometer, model DVIII (Brookfield Engineering Labs., Inc., USA) equipped with a SC4-18/13R spindle and a small sample adaptor in the solution $(6 \mathrm{~mL})$ at $37.0 \pm 0.1^{\circ} \mathrm{C}$. Measurements were made within the shear rates between 0.2 and $45 \mathrm{~s}^{-1}$. Solutions were prepared in triplicate. Apparent viscosities $\eta_{\text {app }}$ (mPas) were defined as the measured viscosities at specific shear rates of $3.86 \mathrm{~s}^{-1}$.

\subsection{DPPH (1,1-Diphenyl-2-picrylhydrazyl) Radical Scaveng-} ing. The DPPH radical scavenging activities of the isolated pectin fractions were assayed according to the method described by Yang et al. [25], with some modifications. The samples (in $50 \mathrm{mM}$ Tris- $\mathrm{HCl}, \mathrm{pH}$ 7.9) were mixed with the DPPH (Sigma-Aldrich) solution $(130 \mu \mathrm{M}$ in ethanol) in a $1: 1$ ratio. The mixture was kept at room temperature for $60 \mathrm{~min}$ in the dark and the absorbance of the resulting solution was measured at $517 \mathrm{~nm}$. Trolox (Sigma-Aldrich) $(650 \mu \mathrm{M}$ in ethanol) was used for the determination of the absorbance of fully quenched DPPH. The radical scavenging activity (RSA) of the samples was expressed as a percentage of the disappearance of DPPH according to the equation

$$
\mathrm{RSA}=\left(\frac{\left(A_{\mathrm{dpph}}-A_{\mathrm{sample}}\right)}{\left(A_{\mathrm{dpph}}-A_{\mathrm{ref}}\right)}\right) \times 100,
$$

where $A_{\mathrm{dpph}}, A_{\text {sample }}$, and $A_{\text {ref }}$ represent the initial absorbance of the DPPH solution, the final absorbance of the DPPH solution with the sample, and those with Trolox, respectively.

2.4. Hydroxyl Radical Scavenging. The hydroxyl RSA of the pectin fractions was assayed as described by Zhao and Jung [26], with some modifications. Each reaction mixture had a final volume of $0.5 \mathrm{~mL}$ and comprised deoxyribose $(3 \mathrm{mM}$, Sigma-Aldrich), PBS (pH 7.4, $100 \mathrm{mM}$ ), $\mathrm{FeCl}_{2}$ (30 $\mu \mathrm{M}$, SigmaAldrich), disodium salt of ethylenediaminetetraacetic acid (EDTA) $(45 \mu \mathrm{M}), \mathrm{H}_{2} \mathrm{O}_{2}$ (0.85 mM, Sigma-Aldrich), ascorbic acid $(1.5 \mathrm{mM})$, and varying concentrations of the sample. The $\mathrm{FeCl}_{2}$ and EDTA were premixed before being added to the reaction mixture. After incubation at $37^{\circ} \mathrm{C}$ for $1 \mathrm{~h}$, the colour was allowed to develop after the addition of $0.25 \mathrm{~mL}$ of cold trichloroacetic acid $(2.8 \% \mathrm{w} / \mathrm{v})$ and $0.5 \mathrm{~mL}$ thiobarbituric acid $(1 \% \mathrm{w} / \mathrm{v}$, in $0.05 \mathrm{M} \mathrm{NaOH})$. These reaction mixtures were heated in a boiling water bath for $15 \mathrm{~min}$ and then cooled to room temperature. The absorbance of the resulting solution was measured at $532 \mathrm{~nm}$. The rate constant for the reaction of a sample with the hydroxyl radical was calculated from the acquired data.
2.5. Xanthine Oxidase (XO) Activity Assay and the Superoxide Scavenging Activity. The enzymatic activity of XO (EC 1.17.3.2, from bovine milk, Sigma-Aldrich) was measured by continuously measuring uric acid formation at $290 \mathrm{~nm}$, with xanthine (Sigma-Aldrich) as the substrate. The XO assay consisted of a $300 \mu \mathrm{L}$ reaction mixture comprising phosphate buffer (50 mM, pH 7.8), EDTA (0.1 mM), XO $(12.5 \mu \mathrm{g} / \mathrm{mL})$, and xanthine $(50 \mu \mathrm{M})$. The assay was initiated by adding the enzyme to the reaction mixture, with or without the test compounds. The assay mixture was incubated at $37^{\circ} \mathrm{C}$ for $4 \mathrm{~min}$, and the absorbance was recorded every $20 \mathrm{~s}$. All data obtained from the enzyme kinetic assays were recorded in matched quartz plates (Hellma, Germany) and were plotted using the KC4 software on a PowerWave 200 microplate scanning spectrophotometer (Bio-Tek Instruments, USA). The inhibition ratio (IR) of the samples was calculated as

$$
\mathrm{IR}=\left(1-\frac{\left(A_{\text {sample }} / \mathrm{min}\right)}{\left(A_{\text {control }} / \mathrm{min}\right)}\right) \times 100,
$$

where $A_{\text {sample }} / \mathrm{min}$ and $A_{\text {control }} / \mathrm{min}$ are the rates of the reaction and $A_{\text {sample }}$ and $A_{\text {control }}$ are the absorbance of the sample and control solutions, respectively. The superoxide radical scavenging activity was measured by xanthine and $\mathrm{XO}$ using ferricytochrome $c$ (from equine heart, $3 \%$ reduced, Fluka, Switzerland). In this system, the superoxide scavenging activity was estimated by measuring the extent of reduction of ferricytochrome $c$ and the extent of inhibition of $\mathrm{XO}$, as has been reported previously [27].

2.6. Determination of the Type of XO Inhibition. The inhibition of XO activity by AC-P and ferulic acid was observed at $25^{\circ} \mathrm{C}$ in phosphate buffer ( $\mathrm{pH} 7.8$ ) using the method described above. Five concentrations of the substrate $(15,20,25,50$, and $100 \mu \mathrm{M})$ were added after preincubating the enzyme with the inhibitor. The XO activities were determined in the presence of pectin fractions $(0.25,0.5$, or $0.75 \mathrm{mg} / \mathrm{mL})$ and ferulic acid $(6.25,12.5$, or $18.75 \mu \mathrm{g} / \mathrm{mL})$. Kinetic parameters of the oxidation of xanthine to uric acid (i.e., maximal velocity $\left(V_{\max }\right)$ and the apparent Michaelis-Menten constant $\left(K_{m}\right)$ ) were calculated as described by Wilkinson [28].

2.7. Statistical Analysis. The data shown are expressed as the means \pm standard deviation $(n=3-4)$. The statistical significance was calculated using the one-way ANOVA with post hoc LCD test $(p<0.05)$. The data for the type of inhibition of $\mathrm{XO}$ are represented by the median of three separate measurements.

\section{Results and Discussion}

3.1. Characterization of Pectin Fractions. Pectin fractions BOP, DC-P, AC-P, and CA-P were isolated from white cabbage, carrot, onion, and sweet pepper, respectively, using a simulated gastric fluid. The yield of the fractions was found to differ in the vegetables studied (Table 1). These differences may be because the raw and edible parts of the vegetables are comprised of different plant tissues [29]. The yield of 
TABLE 1: Yield and chemical properties of the pectin fractions studied.

\begin{tabular}{|c|c|c|c|c|c|}
\hline Pectin fraction & BO-P & DC-P & AC-P & CA-P & $\mathrm{AP}^{\mathrm{c}}$ \\
\hline Yield $^{\mathrm{a}}$ & 0.33 & 0.51 & 0.35 & 0.29 & - \\
\hline \multicolumn{6}{|c|}{ Monosaccharide composition (g/100 g dry solid) } \\
\hline Galacturonic acid & 38.6 & 48.6 & 41.4 & 74.1 & 77.0 \\
\hline Arabinose & 14.1 & 8.6 & 4.3 & 2.1 & 4.1 \\
\hline Galactose & 8.5 & 15.6 & 17.6 & 2.2 & 8.3 \\
\hline Rhamnose & 3.7 & 3.9 & 2.2 & 1.3 & 1.5 \\
\hline Xylose & 2.4 & 1.1 & 1.0 & 1.1 & 1.9 \\
\hline Mannose & 0.2 & 0.2 & 0.2 & - & 0.1 \\
\hline Glucose & 0.8 & 0.5 & 0.6 & 0.5 & 2.9 \\
\hline $\mathrm{DM}(\text { molar\%) })^{\mathrm{b}}$ & 76 & 51 & 66 & 56 & 73 \\
\hline \multicolumn{6}{|l|}{ Molecular weight } \\
\hline $\mathrm{Mn}(\mathrm{kDa})$ & 43 & 79 & 109 & 120 & 49 \\
\hline $\mathrm{Mw}(\mathrm{kDa})$ & 351 & 827 & 900 & 571 & 452 \\
\hline $\mathrm{Mw} / \mathrm{Mn}$ & 8 & 11 & 8 & 5 & 9 \\
\hline
\end{tabular}

${ }^{a}$ Yield is calculated per weight of fresh weight; ${ }^{b} \mathrm{DM}$, degree of methyl esterification; ${ }^{\mathrm{c}}$ commercial pectin.

DC-P was found to be the highest, constituting $0.51 \%$ of the fresh matter. The obtained yields were lower than the amount of soluble dietary fibre in the same vegetable, which were previously reported to be $0.8-1.7 \%[30,31]$. These differences may result from the ultrafiltration procedure used in the present study, which leads to the removal of components with low molecular weight and insoluble fibre. The Mw of the obtained pectins (Table 1) were similar to those of the sodium carbonate-soluble pectins of white cabbage, carrot, and onion obtained in previous studies [32-34].

BO-P, DC-P, AC-P, and CA-P were hydrolyzed with $2 \mathrm{M}$ TFA to release the monosaccharides typically present in pectins. GalUA residues were identified as the main constituents of the sugar chains of pectins (Table 1). The GalUA content of the pectin isolated from sweet pepper (CAP) was found to be the highest (74\%), whereas the other pectins contained 39-48\% GalUA residues. As expected, a considerable portion of the GalUA residues in the pectins were present as methyl esters, with a DM of 51-76\%. Previous studies $[35,36]$ reported the $\mathrm{DM}$ of $\mathrm{HCl}$-extracted pectins from vegetables to be approximately $50-60 \%$. The Ara, Gal, and Rha residues constituted the remaining neutral monosaccharides and appeared to originate from branched rhamnogalacturonan I pectic moieties. In addition, minor amounts of mannose (Man), xylose (Xyl), and glucose (Glc) were detected; these monomers are likely the constituents of the hemicellulose content of the obtained pectin fractions. In general, the Rha/GalUA ratio is considered to be a good indication of the amount of $\mathrm{RG}$ and $\mathrm{HG}$ regions present [37]. From this ratio, it was obvious that BO-P and DC$\mathrm{P}$ were most enriched in $\mathrm{RG}$ with $\mathrm{Rha} / \mathrm{GalUA}$ ratios of 0.08-0.09, whereas CA-P contained the most HG regions with a Rha/GalUA ratio of 0.02 . Corresponding Rha/GalUA ratios for the pectins of white cabbage [34], carrot [38], onion [32], and sweet pepper [39] have been previously reported. The Gal residue content was higher in the pectin fraction obtained from onion compared to the fractions from other vegetables. Significant cleavage of the carbohydrate chains was observed during pectinase treatment of the obtained pectin fractions. The digestion of the samples with pectinase led to the release of free galacturonic acid and insoluble polysaccharides.

The obtained pectin fractions contained 2-9\% protein contaminants, and the amino acid profiles of these protein moieties included 17 amino acids (Table 2). The sum of the aspartic and glutamic acid residues constituted a substantial proportion of the total amino acids (18-23\%). High proportions of serine, glycine, threonine, and leucine were found in the protein moieties of all pectin fractions. Additionally, BO$\mathrm{P}$ and $\mathrm{CA}-\mathrm{P}$ were rich in arginine. Cysteine and methionine residues seemed to be in low proportions in the protein moieties of all the fractions studied. Pectic polysaccharides have been coextracted with protein by others, using different extraction conditions and various sources. Atomic force microscopy data clearly demonstrated the coextraction of pectin with protein, wherein the protein is attached to one end of the pectin chain [40]. Pectin molecules have been suggested to be cross-linked by phenolic compounds and have been known to make up more than $2 \%$ of the cell wall [41]. Low levels of phenolic compounds were present in all the obtained pectin fractions, as measured by the Folin-Ciocalteu assay. CA-P contained approximately $0.3 \%$ phenolics, whereas $0.5-0.7 \%$ phenolics were detected in the other pectin fractions. The presence of protein and phenolics appeared to confirm the view that undigested polysaccharide material could include fractions of other compounds [30].

3.2. DPPH Radical Scavenging Activity. The DPPH radical scavenging activity of the pectin fractions obtained from vegetables increased in a concentration-dependent manner (Table 3) and was found to be similar to the previously published results for apple pomace [42], artichoke [10], and grapefruit peel pectins [12]. However, the pectins of tamarind [43], cactus cladode [44], and Brazilian jambu plant [45] have been shown to exhibit higher anti-DPPH activities (greater 
TABLE 2: Amino acid composition of protein contaminants of the pectin fractions studied ${ }^{\mathrm{a}}$.

\begin{tabular}{|c|c|c|c|c|}
\hline Amino acid (\%) & BO-P & DC-P & AC-P & CA-P \\
\hline Aspartic acid & 12.8 & 9.8 & 7.1 & 11.2 \\
\hline Serine & 8.2 & 7.4 & 6.6 & 7.2 \\
\hline Glutamic acid & 10.2 & 12.5 & 11.7 & 10.6 \\
\hline Glycine & 7.5 & 6.6 & 6.4 & 5.7 \\
\hline Histamine & 3.8 & 1.2 & 1.2 & 4.2 \\
\hline Ammonia & 3.1 & 4.2 & 6.1 & 2.7 \\
\hline Threonine & 7.3 & 6.6 & 7.2 & 8.5 \\
\hline Arginine & 8.0 & 4.8 & 5.2 & 8.5 \\
\hline Alanine & 4.8 & 6.8 & 6.1 & 5.1 \\
\hline Proline & 5.1 & 4.7 & 5.6 & 5.0 \\
\hline Cysteine & 0.5 & 0 & 0.2 & 1.8 \\
\hline Tyrosine & 1.9 & 2.7 & 2.1 & 2.0 \\
\hline Valine & 6.4 & 7.0 & 6.3 & 5.1 \\
\hline Methionine & 0.7 & 0.5 & 0.3 & 0.4 \\
\hline Lysine & 3.0 & 7.4 & 8.7 & 7.2 \\
\hline Isoleucine & 3.9 & 5.0 & 5.3 & 3.8 \\
\hline Leucine & 8.2 & 7.9 & 8.3 & 6.4 \\
\hline Phenylalanine & 4.6 & 4.9 & 5.6 & 4.5 \\
\hline
\end{tabular}

${ }^{a}$ Tryptophan usually suffers complete loss during acid hydrolysis and was therefore not quantified in the analysis.

TABLE 3: The radical scavenging activities of pectin fractions in comparison with calculated activity of ferulic acid contaminant.

\begin{tabular}{|c|c|c|c|c|c|}
\hline \multirow[t]{2}{*}{ Pectin fraction } & \multirow{2}{*}{$\begin{array}{l}\text { Concentration } \\
(\mathrm{mg} / \mathrm{mL})\end{array}$} & \multicolumn{2}{|c|}{ DPPH scavenging (\%) } & \multicolumn{2}{|c|}{$\begin{array}{l}\text { Hydroxyl radical } \\
\text { scavenging (\%) }\end{array}$} \\
\hline & & Fraction & Ferulic acid ${ }^{\mathrm{a}}$ & Fraction & Ferulic acid ${ }^{\mathrm{a}}$ \\
\hline \multirow{3}{*}{$\mathrm{BO}-\mathrm{P}$} & 0.25 & $15 \pm 11^{*}$ & $(12)$ & $3 \pm 2$ & (2) \\
\hline & 0.5 & $20 \pm 9^{*}$ & $(24)$ & $16 \pm 0^{*}$ & $(4)$ \\
\hline & 1 & $31 \pm 6^{*}$ & $(36)$ & $20 \pm 2^{*}$ & $(7)$ \\
\hline \multirow{3}{*}{ DC-P } & 0.25 & $13 \pm 12$ & (9) & $10 \pm 5$ & (1) \\
\hline & 0.5 & $14 \pm 12$ & $(20)$ & $19 \pm 7^{*}$ & (2) \\
\hline & 1 & $25 \pm 11^{*}$ & $(30)$ & $20 \pm 0^{*}$ & $(7)$ \\
\hline \multirow{3}{*}{ AC-P } & 0.25 & $12 \pm 5^{*}$ & (13) & $10 \pm 5$ & (2) \\
\hline & 0.5 & $18 \pm 3^{*}$ & (27) & $20 \pm 9^{*}$ & (5) \\
\hline & 1 & $36 \pm 7^{*}$ & $(39)$ & $30 \pm 6^{*}$ & (6) \\
\hline \multirow{3}{*}{ CA-P } & 0.25 & $6 \pm 4$ & $(4)$ & $11 \pm 2$ & (1) \\
\hline & 0.5 & $11 \pm 12$ & (14) & $12 \pm 4$ & (1) \\
\hline & 1 & $18 \pm 9^{*}$ & $(22)$ & $20 \pm 4^{*}$ & (3) \\
\hline \multirow{3}{*}{ AP } & 0.25 & $7 \pm 14$ & (4) & $9 \pm 4$ & (1) \\
\hline & 0.5 & $3 \pm 4$ & (14) & $10 \pm 1$ & (1) \\
\hline & 1 & $17 \pm 19$ & $(22)$ & $20 \pm 3^{*}$ & $(2)$ \\
\hline
\end{tabular}

${ }^{a}$ Radical scavenging of ferulic acid at a concentration corresponding to the phenolic content of the fraction was calculated using a calibration curve (Figure 1 ) and is shown in the round brackets. Data are expressed as means \pm standard deviation $(n=3) ;{ }^{*}$ mean value is significantly higher than control $(p<0.05)$.

than $50 \%)$ at the same concentration $(1 \mathrm{mg} / \mathrm{mL})$. The potential DPPH scavenging activity of the phenolic contaminants of the pectin fractions studied was estimated using a calibration curve for ferulic acid (Figure 1). The DPPH scavenging activity of ferulic acid, which was measured at concentrations corresponding to the phenolic content of the fractions, exceeded the scavenging activities of the corresponding samples (Table 3). For instance, $1 \mathrm{mg} / \mathrm{mL}$ solutions of BO-P and AC-P (Table 3, bold lines) were measured to contain 6 and $7 \mu \mathrm{g} / \mathrm{mL}$ of phenolics, respectively. Ferulic acid at concentrations of 6 and $7 \mu \mathrm{g} / \mathrm{mL}$ inhibited the DPPH radical to extents of $36 \%$ and $39 \%$, respectively (Figure 1, arrows). This 
TABLE 4: Values of $K_{m}$ and $V_{\max }$ for uric acid production catalyzed by XO in the presence of AC-P and ferulic acid.

\begin{tabular}{|c|c|c|c|c|}
\hline Inhibitor & Concentration $^{\mathrm{a}}$ & $K_{m}$ & $V_{\max }$ & Type \\
\hline \multirow{4}{*}{ AC-P } & 0 & $16 \pm 3$ & $0.037 \pm 0.004$ & \multirow{4}{*}{ Noncompetitive } \\
\hline & 0.25 & $18 \pm 6$ & $0.034 \pm 0.005$ & \\
\hline & 0.5 & $16 \pm 5$ & $0.029 \pm 0.006^{*}$ & \\
\hline & 0.75 & $16 \pm 7$ & $0.025 \pm 0.004^{*}$ & \\
\hline \multirow{4}{*}{ Ferulic acid } & 0 & $19 \pm 8$ & $0.042 \pm 0.008$ & \multirow{4}{*}{ Uncompetitive } \\
\hline & 6.25 & $17 \pm 6$ & $0.041 \pm 0.007$ & \\
\hline & 12.5 & $16 \pm 5$ & $0.039 \pm 0.006$ & \\
\hline & 18.75 & $14 \pm 4$ & $0.036 \pm 0.005$ & \\
\hline
\end{tabular}

${ }^{\mathrm{a}}$ Concentrations of AC-P and ferulic acid are in $\mathrm{mg} / \mathrm{mL}$ and $\mu \mathrm{g} / \mathrm{mL}$, respectively. ${ }^{*}$ Mean value is significantly higher than control $(p<0.05)$.

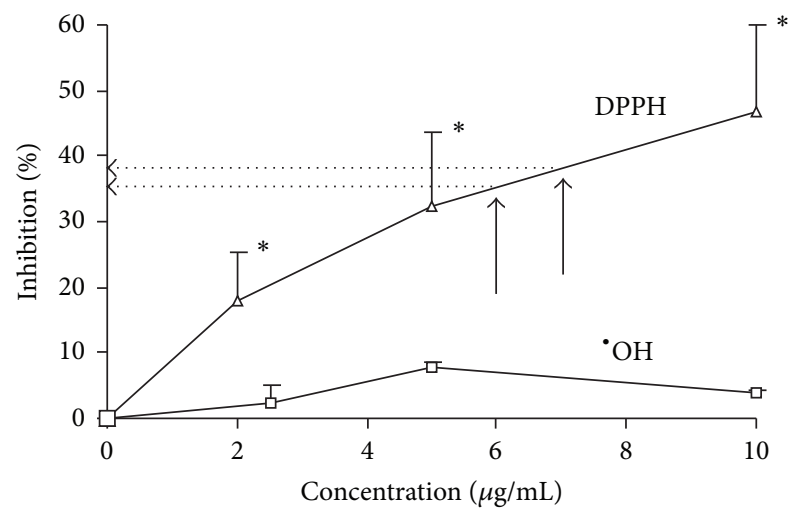

FIGURE 1: The DPPH and the hydroxyl radical $\left({ }^{\circ} \mathrm{OH}\right)$ scavenging activities of ferulic acid. ${ }^{*}$ Value is significantly higher than control $(p<0.05 ; n=3)$.

calculation indicates that the phenolic contaminants appear to provide the RSA for the pectin fractions in the DPPH assay.

3.3. Hydroxyl Radical Scavenging Activity. The obtained pectin fractions possessed hydroxyl radical scavenging activities with efficiencies of $10-30 \%$ (Table 3 ). The scavenging effect increased with increasing fraction concentrations from 0.25 to $1 \mathrm{mg} / \mathrm{mL}$. AC-P possessed a higher hydroxyl radical scavenging activity than the other fractions tested. The hydroxyl radical scavenging activity of the obtained pectin fractions was lower than that of the pectic polysaccharides of Opuntia ficus indica [44]. The rate constant for the reaction between AC-P and the hydroxyl radical was $2.05 \pm 0.56 \times$ $10^{9} \mathrm{M}^{-1} \mathrm{~s}^{-1}$; the other fractions studied had a rate constant in the range of $(1.03-1.37) \times 10^{9} \mathrm{M}^{-1} \mathrm{~s}^{-1}$. The rate constant for the reaction of hydroxyl radicals with a pectin has been estimated previously, to be equal to $7 \times 10^{8} \mathrm{M}^{-1} \mathrm{~s}^{-1}$ [46]. The higher rate constant in our study may be attributed to the presence of protein contaminants. Indeed, the rate constant for the reaction of hydroxyl radical with proteins has been shown to be equal to $8 \times 10^{10} \mathrm{M}^{-1} \mathrm{~s}^{-1}$ [47]. Therefore, AC$\mathrm{P}$ which contains twofold higher amount of protein $(9 \%)$ compared to other pectin fractions (2-4\%) demonstrated a higher rate constant for the reaction with hydroxyl radicals.
According to Xie et al. [48], amino groups of proteins may interact with hydroxyl radicals to form stable macromolecule radicals. Ferulic acid was shown to exhibit only 5\% RSA at concentrations that correspond with the phenolic contents of the fractions (approx. $5 \mu \mathrm{g} / \mathrm{mL}$ ) (Table 3).

3.4. Superoxide Radical Scavenging and the Inhibition of XO Activity. A xanthine/XO system was used to determine the rate of generation of superoxide radicals. Both the superoxide radical scavenging effect and the inhibition of $\mathrm{XO}$ were measured in the same assay. A decreased production of superoxide was measured using the ferricytochrome $c$ reduction assay, and the inhibition of $\mathrm{XO}$ was measured in terms of the production of uric acid.

AC-P decreased the rate of ferricytochrome $c$ reduction (Figure 2). A simultaneous decrease in uric acid production by AC-P was even more prominent than the reduction of the superoxide level. As shown in Figure 2, both the uric acid and the superoxide levels decreased with increasing concentrations of onion fraction, but the superoxide curve (solid line) was lower than the uric acid curve (dotted line). Therefore, onion pectin fraction appeared to inhibit $\mathrm{XO}$ rather than scavenge superoxide radicals.

The production of superoxide radicals by $\mathrm{XO}$, an enzyme present in the gastrointestinal milieu [49], was used in the present investigation. To evaluate the mechanism of the $\mathrm{XO}$ inhibition, the effect of onion fraction on uric acid production was tested at different concentrations of the substrate and inhibitor. From the data available it has been estimated to be $V_{\max }$ and $K_{m}$ (Table 4 ). $K_{m}$ was not changed by AC-P and $V_{\max }$ was decreased. This confirms that the inhibitor preferentially binds to the free enzyme and the enzyme substrate complex at a site other than the active site. For comparison, the effect of ferulic acid on the inhibition of the xanthine/XO complex was examined (Table 4). Distinct modes of XO inhibition by ferulic acid and AC-P indicate that the contaminants of ferulic acid failed to mediate the inhibitory effects of AC-P on XO.

As mentioned above, AC-P demonstrated the highest molecular weight $(900 \mathrm{kDa})$ and had a higher content of Gal residues when compared to the other pectin fractions studied $(\mathrm{Gal} / \mathrm{Ara}=4.1)$. According to our data solution of AC-P demonstrated the highest viscosity compared to 

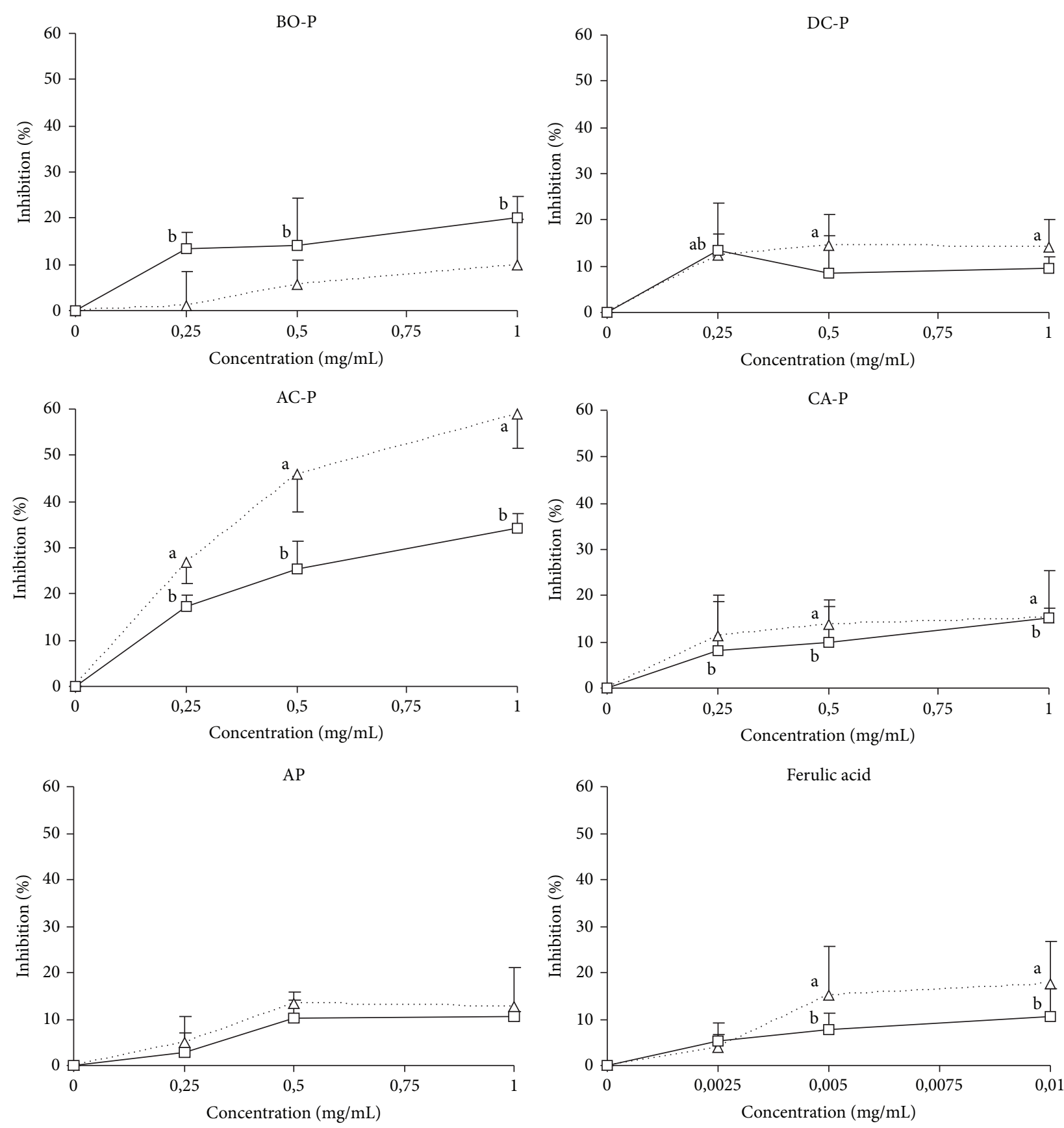

FIGURE 2: The inhibition of xanthine oxidase (dotted line) and reduction of ferricytochrome $c$ (solid line) by pectin fractions and ferulic acid. ${ }^{\mathrm{a}, \mathrm{b}}$ Value is significantly higher than control $(p<0.05 ; n=3-4)$.

that of BO-P, DC-P, and CA-P (392 versus 297, 206, and $67 \mathrm{mPa}$ s). Therefore, the inhibition of XO activity by pectin fractions is suggested to be partly caused by the increase of the medium viscosity depending on the molecular weight of polysaccharides.

Pectin fractions were shown to inhibit XO and scavenge ROS. Inhibition of XO may be mediated by pectic polysaccharide chains, whereas protein and phenolic contaminants are suggested to provide the scavenging of ROS. The data demonstrate each constituent of pectin fractions to be important for implementation of antioxidant effect in the gastrointestinal milieu. It should be noted that the mechanism of antioxidant action differs among pectin fractions studied. For example, AC-P inhibits the XO activity more than scavenging the DPPH and the hydroxyl radical (48 versus $30-36 \%$ ). BO-P, DC-P, and CA-P exert 
a less inhibiting effect on XO than RSA (9-23 versus $17-31 \%)$. Therefore, the antioxidant activity of AC-P predominantly appeared in the inhibition of $\mathrm{XO}$ activity by pectin chains.

\section{Conclusion}

The present study demonstrates that pectin fractions isolated from fresh vegetables by extraction with a simulated gastric fluid possess antioxidant activities that are dependent on their structural features. The pectin fraction from onion, AC-P, was found to inhibit the production of superoxide radical by inhibiting XO. The high molecular weight of AC-P and a large count of Gal residues appeared to provide $\mathrm{XO}$ inhibition. Protein and phenolic contaminants associated with polysaccharide moieties were shown to be responsible for the antioxidant effects of vegetable pectins on the hydroxyl and the DPPH radicals. AC-P was found to inhibit XO activity more than the DPPH and the hydroxyl radical scavenging in opposition to other pectin fractions. It suggests that pectic polysaccharide chains are important for the antioxidant capacity of onion pectin fractions. Differences in the yield of pectin fractions obtained using a simulated gastric fluid indicate that vegetables appear to differ in the bioaccessibility of their polysaccharides with antioxidant activity. The data obtained would be useful for development of new approach in food analysis based on the beneficial effect of pectic polysaccharides and would also provide support for future dietary guidelines.

\section{Abbreviations}

$\begin{array}{ll}\text { AccQ: } & \begin{array}{l}\text { 6-Aminoquinolyl-N- } \\ \text { hydroxysuccinimidyl } \\ \text { carbamate }\end{array} \\ \text { Ara: } & \text { Arabinose } \\ \text { BO-P, DC-P, } & \text { Pectin fractions from white } \\ \text { AC-P, and CA-P: } & \text { cabbage, carrot, onion, and sweet } \\ & \text { pepper, respectively } \\ \text { DM: } & \text { Degree of methyl esterification } \\ \text { DPPH: } & \text { 1,1-Diphenyl-2-picrylhydrazyl } \\ & \text { radical } \\ \text { EDTA: } & \text { Ethylenediaminetetraacetic acid, } \\ \text { disodium } \\ \text { Gal: } & \text { Galactose } \\ \text { GalUA: } & \text { Galacturonic acid } \\ \text { GLC: } & \text { Gas-liquid chromatography } \\ \text { Glc: } & \text { Glucose } \\ \text { HG: } & \text { Homogalacturonan } \\ \text { HPLC: } & \text { High-performance liquid } \\ \text { chromatography } & \text { Mannose } \\ \text { Man: } & \text { Average molecular weight number } \\ \text { Mn: } & \text { Average molecular weight } \\ \text { Mw: } & \text { Rhamnogalacturonan } \\ \text { RG: } & \text { Rhamnose } \\ \text { Rha: } & \text { Reactive oxygen species } \\ \text { ROS: } & \text { Radical scavenging activity } \\ \text { RSA: } & \text { Trifluoroacetic acid } \\ \text { TFA: } & \\ & \end{array}$

XO: Xanthine oxidase

Xyl: Xylose.

\section{Conflicts of Interest}

The authors declare that they have no conflicts of interest.

\section{References}

[1] C. A. Gonzalez, G. Pera, A. Agudo et al., "Fruit and vegetable intake and the risk of stomach and oesophagus adenocarcinoma in the European Prospective Investigation into Cancer and Nutrition (EPIC-EURGAST)," International Journal of Cancer, vol. 118, no. 10, pp. 2559-2566, 2006.

[2] J. K. Hou, B. Abraham, and H. El-Serag, "Dietary intake and risk of developing inflammatory bowel disease: a systematic review of the literature," The American Journal of Gastroenterology, vol. 106, no. 4, pp. 563-573, 2011.

[3] K. Masisi, T. Beta, and M. H. Moghadasian, "Antioxidant properties of diverse cereal grains: a review on in vitro and in vivo studies," Food Chemistry, vol. 196, pp. 90-97, 2016.

[4] K. Dwiecki, A. Siger, J. Czubinski, M. Nogala-Kałucka, and E. Lampart-Szczapa, "The interactions between rapeseed lipoxygenase and native polyphenolic compounds in a model system," JAOCS, Journal of the American Oil Chemists' Society, vol. 89, no. 3, pp. 379-387, 2012.

[5] B. Halliwell, K. Zhao, and M. Whiteman, "The gastrointestinal tract: a major site of antioxidant action?" Free Radical Research, vol. 33, no. 6, pp. 819-830, 2000.

[6] A. Bhattacharyya, R. Chattopadhyay, S. Mitra, and S. E. Crowe, "Oxidative stress: an essential factor in the pathogenesis of gastrointestinal mucosal diseases," Physiological Reviews, vol. 94, no. 2, pp. 329-354, 2014.

[7] Z. A. Popper, "Evolution and diversity of green plant cell walls," Current Opinion in Plant Biology, vol. 11, no. 3, pp. 286-292, 2008.

[8] J. M. Lattimer and M. D. Haub, "Effects of dietary fiber and its components on metabolic health," Nutrients, vol. 2, no. 12, pp. 1266-1289, 2010.

[9] D. Dhingra, M. Michael, H. Rajput, and R. T. Patil, "Dietary fibre in foods: a review," Journal of Food Science and Technology, vol. 49, no. 3, pp. 255-266, 2012.

[10] S. Liu, X. Shi, L. Xu, and Y. Yi, "Optimization of pectin extraction and antioxidant activities from Jerusalem artichoke," Chinese Journal of Oceanology and Limnology, vol. 34, no. 2, pp. 372-381, 2016.

[11] S. S. Venzon, M. Helene, G. Canteri et al., "Physicochemical properties of modified citrus pectins extracted from orange pomace," Journal of Food Science and Technology, vol. 52, pp. 4102-4112, 2015.

[12] W. Wang, X. Ma, P. Jiang et al., "Characterization of pectin from grapefruit peel: a comparison of ultrasound-assisted and conventional heating extractions," Food Hydrocolloids, vol. 61, pp. 730-739, 2016.

[13] A. G. J. Voragen, G.-J. Coenen, R. P. Verhoef, and H. A. Schols, "Pectin, a versatile polysaccharide present in plant cell walls," Structural Chemistry, vol. 20, no. 2, pp. 263-275, 2009.

[14] J. A. Delcour, K. Poutanen, M. Nyman, and L. Haska, "9-Vegetable, fruit and potato fibres," Fibre-Rich and Wholegrain Foods, pp. 193-207, 2013. 
[15] F. Rubio-Senent, Rodriguez-GutierrezG., A. Lama-Munoz, A. Garcia, and J. Fernandez-Bolanos, "Novel pectin present in new olive mill wastewater with similar emulsifying and better biological properties than citrus pectin," Food Hydrocolloids, vol. 50, pp. 237-246, 2015.

[16] Z. Kostalova, Z. Hromadkova, A. Ebringerova, M. Polovka, T. E. Michaelsen, and B. S. Paulsen, "Polysaccharides from the Styrian oil-pumpkin with antioxidant and complement-fixing activity," Industrial Crops and Products, vol. 41, no. 1, pp. 127-133, 2013.

[17] A. Wikiera, M. Mika, A. Starzynska-Janiszewska, and B. Stodolak, "Application of Celluclast 1.5L in apple pectin extraction," Carbohydrate Polymers, vol. 134, Article ID 10153, pp. 251257, 2015.

[18] Food and Agriculture Organization of the United Nations, FAOSTAT Database. Rome, Italy: FAO. http://faostat3.fao.org, 2017.

[19] B. M. Corcoran, C. Stanton, G. F. Fitzgerald, and R. P. Ross, "Growth of probiotic lactobacilli in the presence of oleic acid enhances subsequent survival in gastric juice," Microbiology, vol. 153, no. 1, pp. 291-299, 2007.

[20] R. W. Scott, "Colorimetric determination of hexuronic acids in plant materials," Analytical Chemistry, vol. 51, no. 7, pp. 936-941, 1979.

[21] P. J. Wood and I. R. Siddiqui, "Determination of methanol and its application to measurement of pectin ester content and pectin methyl esterase activity," Analytical Biochemistry, vol. 39, no. 2, pp. 418-428, 1971.

[22] L. D. Melton and B. G. Smith, "Determining the degree of methylation and acetylation of pectin," Current Protocols in Food Analytical Chemistry, pp. 1-6, 2001.

[23] N. Nelson, "A photometric adaptation of Somogyi method for the determination of glucose," The Journal of Biological Chemistry, vol. 153, no. 2, pp. 375-380, 1944.

[24] C. Van Wandelen and S. A. Cohen, "Using quaternary high-performance liquid chromatography eluent systems for separating 6-aminoquinolyl-N-hydroxysuccinimidyl carbamate-derivatized amino acid mixtures," Journal of Chromatography A, vol. 763, no. 1-2, pp. 11-22, 1997.

[25] S.-S. Yang, K.-T. Cheng, Y.-S. Lin, Y.-W. Liu, and W.-C. Hou, "Pectin hydroxamic acids exhibit antioxidant activities in vitro," Journal of Agricultural and Food Chemistry, vol. 52, no. 13, pp. 4270-4273, 2004.

[26] M. J. Zhao and L. Jung, "Kinetics of the competitive degradation of deoxyribose and other molecules by hydroxyl radicals produced by the fenton reaction in the presence of ascorbic acid," Free Radical Research, vol. 23, no. 3, pp. 229-243, 1995.

[27] I. Fridovich, "Quantitative aspects of the production of superoxide anion radical by milk xanthine oxidase," The Journal of Biological Chemistry, vol. 245, no. 16, pp. 4053-4057, 1970.

[28] G. N. Wilkinson, "Statistical estimations in enzyme kinetics," The Biochemical Journal, vol. 80, pp. 324-332, 1961.

[29] M. Roman, M. Baranska, and R. Baranski, "Spectroscopic studies on bioactive polyacetylenes and other plant components in wild carrot root," Journal of Natural Products, vol. 74, pp. 1757-1763, 2011.

[30] J. Lunn and J. L. Buttriss, "Carbohydrates and dietary fibre," Nutrition Bulletin, vol. 32, no. 1, pp. 21-64, 2007.

[31] W. J. Florkowski, R. L. Shewfelt, and B. Brueckner, "Chapter 5-Nutritional quality of fruits and vegetables," in Postharvest Handling, pp. 57-106, 2009.
[32] E. M. O’Donoghue, S. D. Somerfield, M. Shaw et al., "Evaluation of carbohydrates in pukekohe longkeeper and grano cultivars of allium cepa," Journal of Agricultural and Food Chemistry, vol. 52, no. 17, pp. 5383-5390, 2004.

[33] D. N. Sila, E. Doungla, C. Smout, A. Van Loey, and M. Hendrickx, "Pectin fraction interconversions: insight into understanding texture evolution of thermally processed carrots," Journal of Agricultural and Food Chemistry, vol. 54, no. 22, pp. 8471-8479, 2006.

[34] B. Westereng, T. E. Michaelsen, A. B. Samuelsen, and S. H. Knutsen, "Effects of extraction conditions on the chemical structure and biological activity of white cabbage pectin," Carbohydrate Polymers, vol. 72, no. 1, pp. 32-42, 2008.

[35] G. Mesbahi, J. Jamalian, and A. Farahnaky, "A comparative study on functional properties of beet and citrus pectins in food systems," Food Hydrocolloids, vol. 19, no. 4, pp. 731-738, 2005.

[36] N. M. Ptichkina, O. A. Markina, and G. N. Rumyantseva, "Pectin extraction from pumpkin with the aid of microbial enzymes," Food Hydrocolloids, vol. 22, no. 1, pp. 192-195, 2008.

[37] K. Houben, R. P. Jolie, I. Fraeye, A. M. Van Loey, and M. E. Hendrickx, "Comparative study of the cell wall composition of broccoli, carrot, and tomato: structural characterization of the extractable pectins and hemicelluloses," Carbohydrate Research, vol. 346, no. 9, pp. 1105-1111, 2011.

[38] E. Wisker, T. F. Schweizer, M. Daniel, and W. Feldheim, "Fibre-mediated physiological effects of raw and processed carrots in humans," British Journal of Nutrition, vol. 72, no. 4, pp. 579-599, 1994.

[39] M. J. Villanueva-Suarez, A. Redondo-Cuenca, M. D. RodríguezSevilla, and M. De las Heras Martínez, "Characterization of nonstarch polysaccharides content from different edible organs of some vegetables, determined by GC and HPLC: comparative study," Journal of Agricultural and Food Chemistry, vol. 51, no. 20, pp. 5950-5955, 2003.

[40] A. R. Kirby, A. J. MacDougall, and V. J. Morris, "Atomic force microscopy of tomato and sugar beet pectin molecules," Carbohydrate Polymers, vol. 71, no. 4, pp. 640-647, 2008.

[41] K. H. Caffall and D. Mohnen, "The structure, function, and biosynthesis of plant cell wall pectic polysaccharides," Carbohydrate Research, vol. 344, no. 14, pp. 1879-1900, 2009.

[42] X. Wang and X. Lu, "Characterization of pectic polysaccharides extracted from apple pomace by hot-compressed water," Carbohydrate Polymers, vol. 102, no. 1, pp. 174-184, 2014.

[43] R. Sharma, S. Kamboj, R. Khurana, G. Singh, and V. Rana, "Physicochemical and functional performance of pectin extracted by QbD approach from Tamarindus indica L. pulp," Carbohydrate Polymers, vol. 134, pp. 364-374, 2015.

[44] K. Lefsih, C. Delattre, G. Pierre et al., "Extraction, characterization and gelling behavior enhancement of pectins from the cladodes of Opuntia ficus indica," International Journal of Biological Macromolecules, vol. 82, pp. 645-652, 2016.

[45] D. Maria-Ferreira, L. M. Da Silva, D. A. G. B. Mendes et al., "Rhamnogalacturonan from Acmella oleracea (L.) R.K. Jansen: gastroprotective and ulcer healing properties in rats," PLoS ONE, vol. 9, no. 1, Article ID e84762, 2014.

[46] H. Zegota, "The effect of $\gamma$-irradiation on citrus pectin in $\mathrm{N}_{2} \mathrm{O}$ and $\mathrm{N}_{2} \mathrm{O} / \mathrm{O}_{2}$ saturated aqueous solutions," Food Hydrocolloids, vol. 13, no. 1, pp. 51-58, 1999.

[47] M. J. Davies, "Protein oxidation and peroxidation," Biochemical Journal, vol. 473, no. 7, pp. 805-825, 2016. 
[48] W. Xie, P. Xu, and Q. Liu, "Antioxidant activity of water-soluble chitosan derivatives," Bioorganic and Medicinal Chemistry Letters, vol. 11, no. 13, pp. 1699-1701, 2001.

[49] H. M. Martin, K. P. Moore, E. Bosmans et al., "Xanthine oxidoreductase is present in bile ducts of normal and cirrhotic liver," Free Radical Biology and Medicine, vol. 37, no. 8, pp. 12141223, 2004. 

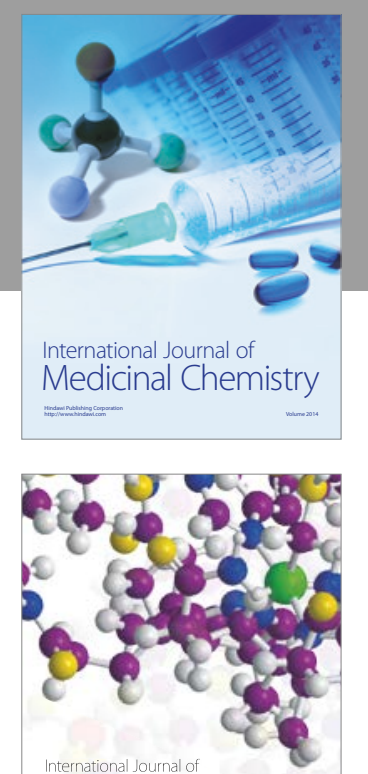

Carbohydrate Chemistry

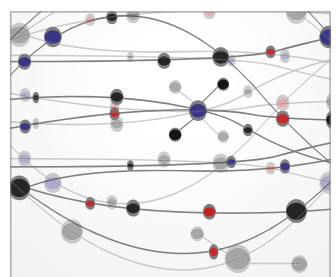

The Scientific World Journal
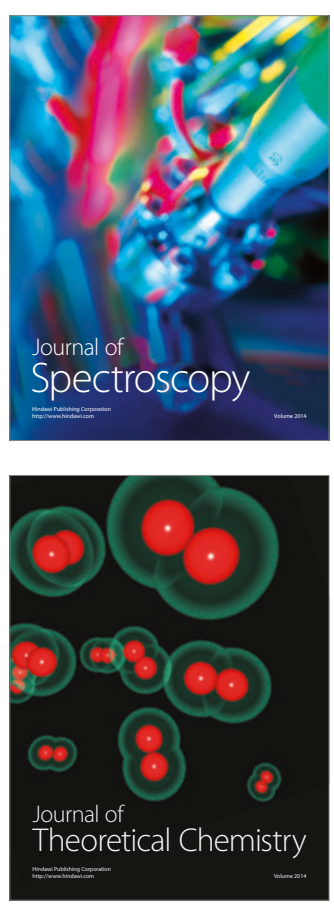
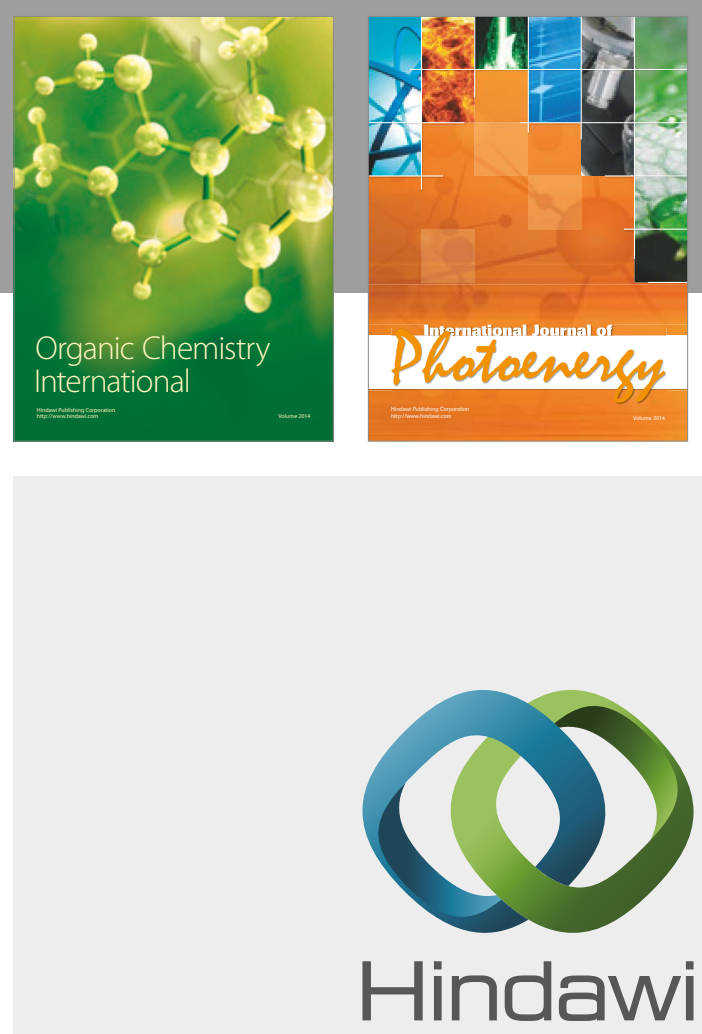

Submit your manuscripts at

https://www.hindawi.com

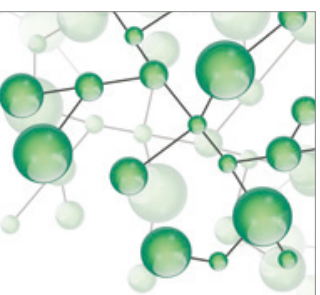

International Journal of

Inorganic Chemistry

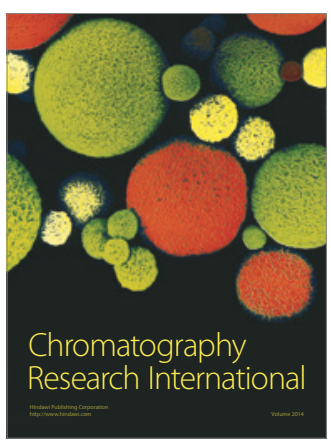

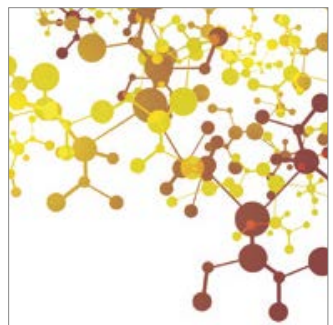

Applied Chemistry
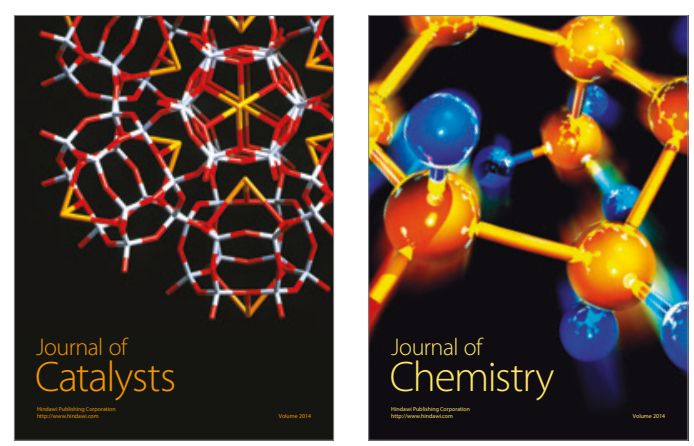
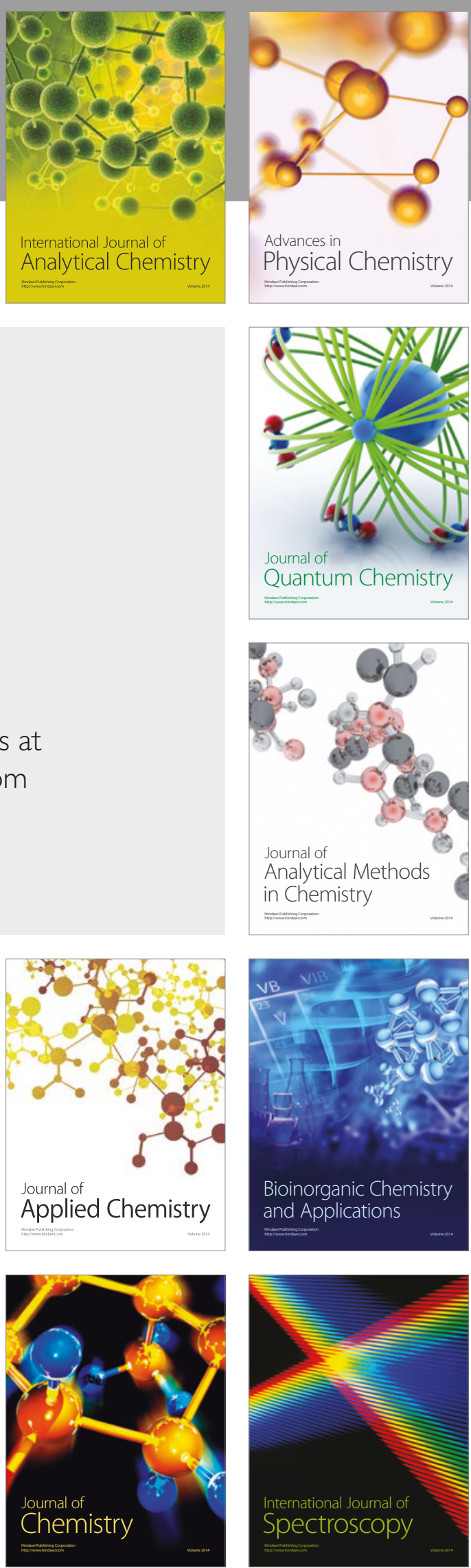